AGRO EKONOMI, Vol 29, No 1, Juni 2018, Hal.146-159

DOI : http://doi.org/ 10.22146/ae.31491

ISSN 0215-8787 (print), ISSN 2541-1616 (online)

Tersedia online di https://jurnal.ugm.ac.id/jae/

\title{
THE IMPACT OF QUALITY OF WORK LIFE AND JOB SATISFACTION ON EMPLOYEE PERFORMANCE OF PT. MADUBARU PG-PS MADUKISMO
}

\section{Pengaruh Kualitas Kehidupan Kerja Dan Kepuasan Kerja Terhadap Kinerja Karyawan PT. Madubaru PG-PS Madukismo}

\author{
Nurma Asri Asharini ${ }^{1}$, Suhatmini Hardyastuti ${ }^{2}$, Irham ${ }^{3}$ \\ ${ }^{1}$ Master Students of Agribusiness Management, Faculty of Agriculture, Universitas \\ Gadjah Mada \\ ${ }^{2,3}$ Faculty of Agriculture, Universitas Gadjah Mada \\ J1. Flora, Bulaksumur, Caturtunggal, Kec.Depok, Kabupaten Sleman, \\ Daerah Istimewa Yogyakarta \\ nurmaasri_asharini@yahoo.com
}

Diterima tanggal : 20 Desember 2017 ; Disetujui tanggal : 17 Juli 2018

\begin{abstract}
This study aimed to (1) determine the effect of the quality of work life (QWL) and job satisfaction to organizational commitment ; (2) finding out the effect of the QWL, job satisfaction, organization commitment to employee performance ; (3) finding out the effect of the QWL and job satisfaction to employee performance with organization commitment as intervening variable. The sample in this research was employees of PT. Madubaru PG-PS Madukismo in Yogyakarta using 100 respondents; the sampling technique was using simple random sampling technique. The types of data used were primary and secondary data with data collecting techniques of survey approach (questionnaire). The data analysis technique used was Structural Equation Modeling (SEM) through AMOS 21 program and SPSS 23. The result of the research is that QWL does not affect the organizational commitment while job satisfaction affects the organizational commitment. The QWL and job satisfaction do not affect employees' performance, while organizational commitment affects the employees' performance. The QWL does not affect the employees' performance indirectly. Job satisfaction affects employees' performance indirectly with organizational commitment as intervening variable. The company should further enhance the employees' organizational commitment in order to higher the employees' performance.
\end{abstract}

Keywords: employee performance; quality of work life

\section{INTISARI}

Penelitian ini bertujuan untuk (1) mengetahui pengaruh kualitas kehidupan kerja (QWL) dan kepuasan kerja terhadap komitmen organisasi ; (2) mengetahui pengaruh QWL, kepuasan kerja, komitmen kerja terhadap kinerja karyawan; (3) mengetahui pengaruh QWL dan kepuasan kerja terhadap kinerja karyawan dengan komitmen organisasi sebagai variabel intervening. Sampel dalam penelitian adalah karyawan PT. Madubaru PG-PS Madukismo di Yogyakarta yang berjumlah 100 responden, teknik pengambilan sampel dengan menggunakan 
teknik simple random sampling. Jenis data yang digunakan adalah data primer dan sekunder dengan teknik pengumpulan data menggunakan pendekatan survei (kuesioner). Teknik analisis data yang digunakan adalah Structural Equation Modelling (SEM) melalui program AMOS 21 dan SPSS 23. Hasil penelitian adalah QWL tidak berpengaruh terhadap komitmen organisasi sedangkan kepuasan kerja berpengaruh terhadap komitmen organisasi. QWL dan kepuasan kerja tidak berpengaruh terhadap kinerja karyawan, sedangkan komitmen organisasi berpengaruh terhadap kinerja karyawan. QWL tidak berpengaruh terhadap kinerja karyawan secara tidak langsung. Kepuasan kerja berpengaruh terhadap kinerja karyawan secara tidak langsung dengan komitmen organisasi sebagai variabel intervening. Perusahaan hendaknya lebih meningkatkan komitmen organisasi karyawan agar kinerja karyawan semakin tinggi.

Kata kunci : kinerja karyawan; kualitas kehidupan kerja

\section{INTRODUCTION}

A company which concerns on agricultural industry is a company engaged in the processing of raw materials from agricultural activities that are processed into finished goods. In a company there are a lot of manpower and factory machineries. The raising of competition in this globalization era forces the company to improve its product quality and employee performance in order to survive and keep developing.

One of agriculture industry is sugar processing industry which is also called sugar factory. One of the companies engaged in this processing sugar is PT Madubaru PG-PS Madukismo in Yogyakarta. This Sugar Factory started producing in 1958 and the Spiritus Factory began producing in 1959 . The sugar factory is still working now.

The resources are everything that included in the company asset and used to achieve the company's goals. Employees are the main resource assets of an organization that have very strategic roles, such as thinkers, planners, and implementer of organizational activities. The success factor of a company is always depending on the human resource management whether it can be well performed or not like PT Madubaru PG-PS Madukismo in Yogyakarta.

As previously mentioned, the performance of a company to achieve its goals is influenced by the performance of its existing employees within the company itself. The employee performance according to Mangkunegara (2008), is the quality of work and quantity achieved by employees in performing their duties in accordance with the responsibilities that given to them by the company management. Factors that have a significant effect on employee performance are the understanding on SOP and work relationship. SOP understanding will bring employees to work in accordance with the expected performance. A good work relationship between employees 
and between employees and management, provide motivation to employees to achieve the expected performance (Sudibyo, Hartono, \& Maas, 2014).

There are many factors that can affect the performance of employees including the quality of work life, organizational commitment and employee job satisfaction. According to research conducted by Arifin (2012), the quality of work life is very influential on the employee performance. There are three indicators in the measurement of quality of work life, those are innovative rewards system, work environment and employee restructuring.

The quality of work life programs are implemented by treating employees fairly and supportively, opening all channels of communication and in all directions, offering employees the opportunity to participate in decisions that affect them and empower them to handle the tasks (Riady, 2009). Job satisfaction by Brayfield \& Rothe (1951) is described as a person's perspective, both positive and negative about his/her work. (Robbins \& Judge, 2008) define organizational commitment as the high involvement of individual employee, or taking a side with a particular job. A high organizational commitment means favoring the organization that recruits the individual.

A research conducted by Irawati (2015) and Mukuan (2014) states that the quality of work life is a factor that has to be considered by the company management because it surely affects the employee performance. Kristianto, Suharnomo, \& Ratnawati (2011) also mentions that job satisfaction has positive and significant impact on employee performance and organizational commitment.

Nurandini \& Lataruva (2014) explain that organizational commitment includes affective commitment, continuous commitment and normative commitment that provenly can influence the employee performance. Affective commitment has the greatest impact on employee performance. In accordance with the studies conducted by Parinding (2015) and Sapitri (2016), they found similar results from their respective studies, for instance organizational commitment consisted of affective commitment, continuous commitment, and normative commitment that had a positive and significant impact on employee performance. Adiftiya (2014) in his research also states that there is an influence between organizational commitment and employee performance. But it has a low level of relationship. The quality of work life, job satisfaction, and commitment also provenly affect employee performance (Lumbantoruan, 2015).

PT. Madubaru PG-PS Madukismo conducts employee performance appraisal once a year. The performance appraisal aims to determine about how far the employees successfully working and completing 
their tasks during the employment period determined by the company.

The performance appraisal is implemented to each employee by assigning Ex (Excellent), G (Good), E (Enough) and L (Less). The employee performance target expected by the company is the result of the performance appraisal of the employees with the score of Ex (Excellent) and G (Good) which is minimally $50 \%$ or half of the total employee in the company during each assessment period.

From table 1 it can be defined that the employee performance was decreasing from 2011-2016. Therefore the management needs to pay attention to things that affect employee performance, so it can create policies that will improve employee performance.

Table 1. Performance Appraisal Data of Employees of PT. Madubaru PG-PS Madukismo of 2011-2016

\begin{tabular}{cccccc}
\hline \multirow{2}{*}{ Year } & Number of & \multicolumn{4}{c}{ Percentage (\%) } \\
\cline { 3 - 6 } & employees & Ex & G & E & L \\
\hline 2011 & 283 & 0 & 22.26 & 76.68 & 1.06 \\
2012 & 292 & 0 & 71.91 & 27.39 & 0.70 \\
2013 & 310 & 0 & 56.78 & 42.58 & 0.64 \\
2014 & 330 & 0 & 47.27 & 50.91 & 1.82 \\
2015 & 325 & 0.31 & 49.54 & 48.92 & 1.23 \\
2016 & 387 & 0 & 0 & 99.74 & 0.26 \\
\hline
\end{tabular}

Source: PT. Madubaru PG-PS Madukismo, 2016.

Employee performance it self is influenced by many factors, such as the quality of work life, job satisfaction and organizational commitment. In this study, the organizational commitment is positioned as intervening variable or intermediate variable on the influence of quality of work life and job satisfaction indirectly to the employee performance.

Thus, this study aims to analyze the effect of quality of work life and job satisfaction on organizational commitment of employees; analyze the influence of quality of work life, job satisfaction, and organizational commitment to employee performance; analyze the influence of quality of work life and job satisfaction on employee performance with organizational commitment as intervening variable.

\section{METHODS}

This research was conducted at PT. Madubaru PG-PS Madukismo which is located at Tromol Post 49 Padokan, Tirtonirmolo, Kasihan, Bantul, Yogyakarta. The research was carried out in MarchJune 2017. The population in this research is employees of PT. Madubaru PG-PS Madukismo. The sample is determined using simple random sampling technique, with the total sample of 100 employees. The type of data used is primary data by using questionnaire. The questionnaire contains statements - giving score for each answer using Likert scale.

To analyze (1) the effect of quality of work life and job satisfaction on organizational commitment of employees; (2) analyze the influence of quality of work 
life, job satisfaction, and organizational commitment to employee performance; (3) analyze the influence of quality of work life and job satisfaction on employee performance with organizational commitment as intervening variable are used SEM or Structural Equation Modeling.

Data analysis technique used in order to test hypothesis in this research is SEM or Structural Equation Modeling with Sample Size Test, Data Normality Test, Outlier Test, Validity Test, Reliability Test, Simultaneous Test with Goodness of Fit Model.

The model of this research is as picture 1 .

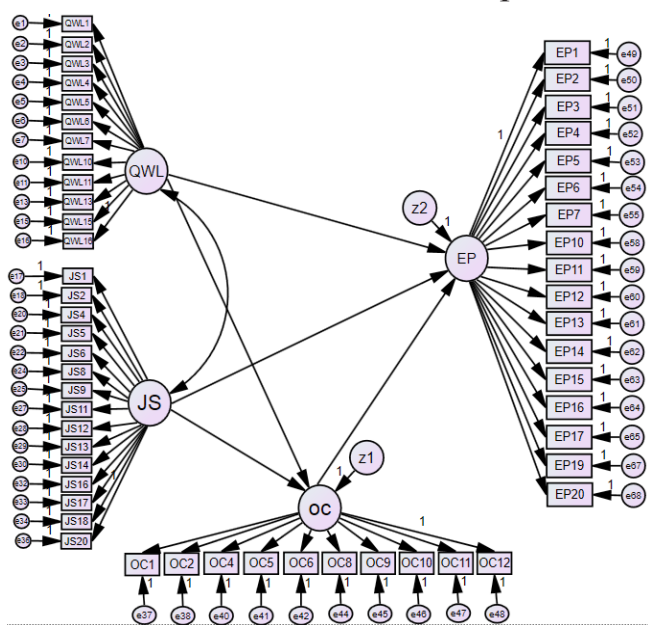

Figure 1. Measurement Model

The variable in this research consists of exogenous variables (Quality of Work Life and Job Satisfaction), endogen variable (Employee Performance) and intervening variable (Organizational Commitment). Quality of work life is measured by the dimensions adopted from (Cascio, 2003): participation of employees, employee development, reward systems and work environment. Dimensions of job satisfaction was adopted from (Robbins, 1996): the work it self, salaries, promotional opportunities, the level and quality of supervision, relationship colleague. Employee performance is measured by the dimensions adopted from (Mangkunegara, 2008): the quantity of work, quality of work, work achievement, work behavior and responsibility.

The organizational commitment measure adopted for this study was the one developed by Allen \& Meyer (1990): affective commitment, continuance commitment, and normative commitment.

\section{RESULTS AND DISCUSSION}

\section{Validity Test, Reliability Test, and}

\section{Normality Test}

Quality of work life is measured by 4 dimensions. Each dimension measured with 4 indicators so that there are 16 indicators. After validity, reliability, and normality test, an indicator that the test passes totaling 12 indicators.

Job satisfaction is measured by the 5 dimensions, each dimension is measured with 4 indicators. So the indicators of job satisfaction totalling 20 indicators. After validity, reliability, and normality test, an indicator that the test passes totaling 15 indicators. 
Furthermore, Employees performance measured by 5 dimensions. Each dimension measured with 4 indicators so that there are 20 indicators. After validity, reliability, and normality test, an indicator that the test passes totaling 12 indicators.

Organizational commitment is measured by the 5 dimensions, each dimension is measured with 3 indicators. So the indicators of job satisfaction totalling 12 indicators. After validity, reliability, and normality test, an indicator that the test passes totaling 10 indicators.

\section{Outliers Test}

The resulting mahalanobis distance value is $x^{2}(68,0.001)=109.791$. The result of the outonobobic distance outlier test is known that no dalanquin value of d-squared is above 109.791 thus it is said to be multivariately no outlier.

\section{Multicollinearity Test}

The multicollinearity test results can be determined by the determinant of sample covariance matrix by 0.000 . Because the value is 0 , then it concludes multicollinearity, however it is still acceptable because the requirements of other SEM assumptions are fulfilled, are the number of samples is at least 100 , and based on CFA test all items are valid (the invalid one was already deleted).

\section{Goodness of Fit Model}

The test results of goodnest of fit are as follows:

Table 2. Goodness of Fit Test Results

\begin{tabular}{lccl}
\hline $\begin{array}{c}\text { Goodness } \\
\text { of Fit }\end{array}$ & $\begin{array}{c}\text { Cut off } \\
\text { value }\end{array}$ & Results & Decision \\
\hline $\begin{array}{l}\text { Probabilitas } \\
\text { Chi Square }\end{array}$ & $\geq 0.05$ & 0.00 & Bad Fit \\
CMIN/DF & $\leq 2.00$ & 1.68 & Good Fit \\
GFI & $\geq 0.90$ & 0.56 & Bad Fit \\
AGFI & $\geq 0.90$ & 0.53 & Bad Fit \\
CFI & $\geq 0.90$ & 0.69 & Bad Fit \\
TLI & $\geq 0.90$ & 0.67 & Bad Fit \\
NFI & $\geq 0.90$ & 0.48 & Bad Fit \\
RMSEA & $\leq 0.08$ & 0.08 & Bad Fit \\
RMR & $\leq 0.05$ & 0.08 & Bad Fit \\
\hline
\end{tabular}

Source: Primary Data Processed, 2017

It was found that only the value of CMIN/DF 1,677 is already fit while the other criteria is not fit or bad fit. So overall the model can not be said as fit, therefore, model modification will be performed. Modified model is done by interconnecting or covariating between variables on the model in accordance with the the recommended by AMOS (on output Modification Indices, fter modification model was performed, it was found that CMIN/DF, CFI, TLI, RMSEA and RMR is fit or good fit. According to Ghozali (2012) in Haryono (2017), overall goodness of fit can be assessed by at least 5 criteria. Therefore after modification of the model, overall model of this research is regarded as fit. 
Table 3. Goodness of Fit Test Results after Modification of the Model

\begin{tabular}{lccl}
\hline $\begin{array}{c}\text { Goodness } \\
\text { of Fit }\end{array}$ & $\begin{array}{c}\text { Cut off } \\
\text { value }\end{array}$ & Results & Decision \\
\hline $\begin{array}{l}\text { Probabilitas } \\
\text { Chi Square }\end{array}$ & $\geq 0.05$ & 0.00 & Bad Fit \\
CMIN/DF & $\leq 2.00$ & 1.19 & Good Fit \\
GFI & $\geq 0.90$ & 0.69 & Bad Fit \\
AGFI & $\geq 0.90$ & 0.63 & Bad Fit \\
CFI & $\geq 0.90$ & 0.92 & Good Fit \\
TLI & $\geq 0.90$ & 0.91 & Good Fit \\
NFI & $\geq 0.90$ & 0.66 & Bad Fit \\
RMSEA & $\leq 0.08$ & 0.04 & Good Fit \\
RMR & $\leq 0.05$ & 0.00 & Good Fit \\
\hline
\end{tabular}

Source: Primary Data Processed, 2017

The Effect of Quality of Work Life and Job Satisfaction to Organizational

\section{Commitment Of Employees}

Based on table 4 , the $p$ value between the quality of work life with organizational commitment is $0.386>0.05$ that is the quality of work life has no positive effect on organizational commitment. The $\mathrm{p}$ value between job satisfaction and organizational commitment is $0.049<0.05$ that is job satisfaction has a positive effect on organizational commitment.

Quality of work life has no positive effect on organizational commitment. Many studies have shown that the quality of work life has a significant positive effect on organizational commitment, including research from Chrisienty (2015), Sudaryatun (2014), Imanni \& Witjaksono (2014). But in this study, the results show that the quality of work life has no direct significant positive effect on organizational commitment. This means that the existing organizational commitment within the employees of PT. Madubaru PG-PS Madukismo is not directly affected by the quality of work life in the company. This can happen, as there may be other independent (exogenous) variables that have a greater impact on organizational commitment. Other exogenous variables in this research is the job satisfaction variable. Employees of PT. Madubaru PGPS Madukismo argued if a high perceived job satisfaction will further enhance the organizational commitment of employees to the company rather than the quality of working life.

Furthermore, job satisfaction have a positive effect on organizational commitment. This means that job satisfaction affects organizational commitment, the higher the level of employee satisfaction, the higher the commitment of the employee's organization. The employees of PT. Madubaru PG-PS Madukismo was satisfied against his job now, satisfied against the given salary, satisfied against the chance of promotion is good, satisfied the quality level and against a provisional, satisfied against a good co-worker relationships. The job satisfaction of the employee is able to improve the organizational commitment of employees of PT. Madubaru PG-PS Madukismo. 
This is in accordance with the results of Kristianto's research, et al. (2011) which shows that job satisfaction positively and significantly affects organizational commitment. A high job satisfaction will increase employees' organizational commitment to the company.

Table 4. Hypothesis Test Results of the effect of Work Life and Job Satisfaction Quality to Organizational Commitment of Employees

\begin{tabular}{cccl}
\hline Relation & $\begin{array}{c}\mathrm{p} \\
\text { Value }\end{array}$ & $\begin{array}{c}\text { Esti } \\
\text { mate }\end{array}$ & \multicolumn{1}{c}{ Note } \\
\hline OC $\leftarrow$ JS & 0.049 & 0.961 & Significant \\
OC $\leftarrow$ QWL & 0.386 & 0.272 & $\begin{array}{l}\text { Not } \\
\text { Significant }\end{array}$ \\
\hline
\end{tabular}

Source: Primary Data Processed, 2017

The Effect of Quality of Work Life, Job Satisfaction, and Organizational

\section{Commitment to Employee Performance}

Based on table 5, the $p$ value between the quality of work life with employee performance is $0.294>0$. that is the quality of work life has no positive effect on employee performance. The $\mathrm{p}$ value between job satisfaction with employee performance is $0.610>0.05$ that is job satisfaction does not have positive effect on the employee performance. Then $\mathrm{p}$ value between organizational commitment with employee performance is $0.026<0.05$ that is the organizational commitment have a positive effect on employee performance.
Table 5. Hypothesis Test Results of the Effect of Quality of Work Life, Job Satisfaction, and Organizational Commitment to Employee Performance

\begin{tabular}{cccc}
\hline Relation & $\begin{array}{c}\mathrm{p} \\
\text { Value }\end{array}$ & $\begin{array}{c}\text { Esti } \\
\text { mate }\end{array}$ & Note \\
\hline EP $\leftarrow$ QWL & 0.294 & -0.506 & $\begin{array}{c}\text { Not } \\
\text { Significant }\end{array}$ \\
EP $\leftarrow$ OC & 0.026 & 1.799 & Significant \\
EP $\leftarrow$ JS & 0.610 & -0.530 & $\begin{array}{c}\text { Not } \\
\text { Significant }\end{array}$ \\
\hline
\end{tabular}

Source: Primary Data Processed, 2017

Quality of work life does not have positive effect on employee performance. So it is said that the performance of employees of PT. Madubaru PG-PS Madukismo is not directly influenced by the quality of work life. Many studies have shown that the quality of work life that affects employee performance, such as research by Irawati (2015) and Mukuan, (2014). But in this study, it was found that the quality of work life has no effect on employee performance. This may be due to the possibility that there is a greater influence of the independent (exogenous) variable on employee performance.

Similarly, job satisfaction does not have positive effect on employee performance. This means that the employee performance of PT. Madubaru PG-PS Madukismo is not directly affected by job satisfaction. There is a possibility that there are other independent (exogenous) variables which influence is greater than 
job satisfaction on employee performance. Several studies also show similar results to this study, such as research by Windari (2014) which shows that job satisfaction variable has no significant effect on employee performance.

The quality of work life and job satisfaction directly has no effect on performance of employees as there are other variables that is a commitment the organization more influential on performance of employees of PT. Madubaru PG-PS Madukismo.

The result of hypothesis test shows that organizational commitment has positive effect on employee performance. This means that the employee's organizational commitment affects employee performance, the higher the organization's commitment, the higher the employee's performance.

Organizational commitment that includes continuance commitments, affective commitments and normative commitments have positive effect on performance of the employees of PT. Madubaru PS PG-Madukismo. Affective commitment in employees feel has become part of the family at the company, employees consider the issue of the company's employees is a problem too, as well as employees feel to have company. Continuance commitment in this study were found to lose if left his job at the moment, employees feel the need now, as well as his employees feel would trouble got a new job if it is moved or out of PT. Madubaru PG-PS Madukismo. Furthermore in the normative commitment employees feel devoted and loyal to the company, employees feel is unethical if it moved to other companies, employees have a moral obligation to remain working at the company and employees not immediately move if there is a new job offer. The presence of the organization's commitment in employees, resulted in the employees choose to keep working with both the company and improve its performance to advance and develop the company in order to be better again.

The results are in line with research by Rosita \& Yuniati, (2016) which shows that organizational commitment has a significant positive effect on employee performance. Indicator of commitment used was affective commitment, that is becoming a member of an organization because it is desired; continuance commitment, that is becoming being a member of an organization because of the need; normative commitment that is becoming a member of an organization because feels obligated. In research by Nurandini \& Lataruva (2014), it explains that organizational commitment that includes affective commitment, continuance commitment and normative commitment are proven to influence employee performance. Affective commitment has the biggest impact on employee performance. 
The Effect of Quality of Work Life and Job Satisfaction on Employee Performance with Organizational

\section{Commitment as Intervening Variable}

According to Mackinnon in Urbayatun \& Widhiarso (2012) variables are said to be intervening or mediators when independent variables affects the mediator which subsequently mediator affects dependent although independent does not significantly affect dependent. In this study, the quality of work life does not directly affect employee performance. The quality of work life has no direct effect on organizational commitment, and organizational commitment directly affects employee performance. Therefore it can be said that indirectly the quality of work life has no effect on employee performance. Although if viewed from the result of standardized direct effect test and standardized indirect effect, organizational commitment proved to be intervening or mediator variable because the value of indirect effect (standardized indirect effect) is 0.488 bigger than the value of direct influence (standardized direct effect) of -0.503 .

Table 6. Direct Effect Test Results

\begin{tabular}{lcccc}
\hline & JS & QWL & OC & EP \\
\hline OC & 0.685 & 0.280 & 0.000 & 0.000 \\
EP & -0.365 & -0.503 & 1.739 & 0.000 \\
\hline
\end{tabular}

Source: Primary Data Processed, 2017
Table 7. Indirect Effect Test Results

\begin{tabular}{lcccc}
\hline & JS & QWL & OC & EP \\
\hline OC & 0.000 & 0.000 & 0.000 & 0.000 \\
EP & 1.192 & 0.488 & 0.000 & 0.000 \\
\hline
\end{tabular}

Source: Primary Data Processed, 2017

Furthermore in this study, it was found that the direct job satisfaction has no effect on employee performance. But indirectly, job satisfaction affects employee performance. It can be said as such because the direct job satisfaction affects the organizational commitment and organizational commitment affects the performance. So it is said that indirect effect of job satisfaction on performance through organizational commitment as intervening variable is occured. Organizational commitment also proved to be an effective intervening variable, judging from the value of indirect effect (standardized indirect effect) of 1.192 which is greater than the value of direct influence (standardized direct effect) on the table that is equal to -0.365 .

The result of hypothesis test shows that there is indirect influence between job satisfaction and employee performance with organizational commitment as intervening variable. In this research job satisfaction does not directly affect the performance of employees of PT. Madubaru PG-PS Madukismo, but job satisfaction indirectly affects the performance of employees with organizational commitment as 
intervening variable. Job satisfaction will have a higher impact on employee performance, if mediated by organizational commitment. High job satisfaction will increase employees' commitment to the company that will also indirectly improve employee performance.

Employee satisfaction to work that matches the expectations of employees, work with hours of work and work schedules that match expectations and jobs that provide an interesting challenge will increase employee commitment to the company. Provision of salary as appropriate responsibilities, in accordance with the wishes of employees, and in accordance with the work of employees will increase satisfaction which furthermore increase the commitment of the organization. Promotion of career ladder in the hope, promotion of employees fairly, and the increase in the ability of employees with training will also make employees feel satisfied. Furthermore, employers who understand the problems of employees, appreciate the work of employees, and good cooperation relationships will generate comfort for employees and improve employee job satisfaction. Good friend or co-worker's attitude, good interpersonal relationships, and mutual respect will foster employee morale and job satisfaction that will enhance organizational commitment.
Increased job satisfaction will further improve employee performance.

Another research that is in line with this research is one by Rosita (2016), job satisfaction has an indirect effect on employee performance through organizational commitment. It was found that the result of the study indicates that organizational commitment is a significant intervening variable in the relationship between job satisfaction and employee performance. Job satisfaction affects the level of commitment of the organization's members to its organization and its consequences, commitment brings to the organization members efforts on their work and on the level of employee performance.

\section{CONCLUSIONS AND SUGGESTION}

Based on the results and discussion, the conclusions in this study are quality of work life has no positive effect on organizational commitment. While job satisfaction has positive effect on organizational commitment of employees of PT. Madubaru PG-PS Madukismo.

Quality of work life and job satisfaction does not have positive effect on employee performance. While organizational commitment has positive effect on employee performance of PT. Madubaru PG-PS Madukismo .

Quality of work life does not affect the performance of employees indirectly. There is an indirect influence between job 
satisfaction and employee performance

with organizational commitment as intervening variable.

The researcher's suggestion for this research are the company should further increase the employee's organizational commitment for higher employee performance. Conducting further research on the performance of employees to find out what things actually affect the performance of employees .

\section{REFERENCES}

Adiftiya, J. (2014). Pengaruh komitmen organisasi terhadap kinerja karyawan pada PT. Bukit Makmur Mandiri Utama site Kideco Jaya Agung Batu Kajang kabupaten Paser. eJournal Ilmu Administrasi Bisnis, 2(4), 833-845. Retrieved from ejournal. adbisnis.fisip-unmul.ac.id

Allen, N. ., \& Meyer, J. P. (1990). The measurement and antecedent of affective, continuance and normative commitment to the organization. $J$ Occupational Psychological Society, 63, 1-18.

Arifin, N. (2012). Analisis kualitas kehidupan kerja, kinerja, dan kepuasan kerja pada CV. Duta Senenan Jepara. Jurnal Economia, 8(1), 11-21. Retrieved from www. journal.uny.ac.id
Brayfield, A. H., \& Rothe, H. F. (1951). An index of job satisfaction. Journal of Applied Psychology, 35(5), 307-311.

Cascio, W. F. (2003). Managing human resources, productivity, quality of work life and profits. Singapore: Irwin Mc Graw Hill Inc.

Chrisienty, W. O. (2015). Pengaruh quality of work life terhadap komitmen organisasional karyawan di CV Sinar Plasindo. AGORA, 3(2), 483490. Retrieved from http://www. studentjournal.petra

Haryono, S. (2017). Metode SEM untuk penelitian manajemen dengan AMOS Lisrel PLS (Cetakan I). Jakarta: Luxima Metro Media.

Imanni, R. N., \& Witjaksono, A. D. (2014). Pengaruh kualitas kehidupan kerja terhadap komitmen organisasi melalui motivasi. Jurnal Ilmu Manejemen, 2(3), 1080-1094. Retrieved from http://jurnalmahasiswa.unesa.ac.id

Irawati, S. A. (2015). Pengaruh kualitas kehidupan kerja terhadap kinerja pegawai Dinas Perindustrian dan Perdagangan kabupaten Sampang. Jurnal Neo-Bis, 9(2), 41-52. Retrieved from http://journal. trunojoyo.ac.id 
Kristianto, D., Suharnomo, \& Ratnawati,

I. (2011). Pengaruh Kepuasan Kerja

Terhadap Kinerja Karyawan Dengan

Komitmen Organisasional Sebagai

Variabel Intervening. Jurnal Bisnis

Dan Ekonomi, 10(1), 1-11. Retrieved

from http://www.eprints.undip.ac.id

Lumbantoruan, E. R. (2015). Pengaruh

kualitas kehidupan kerja, kepuasan

kerja dan komitmen karyawan

terhadap kinerja karyawan dan

prilaku kewargaan sebagai variabel

intervening (studi pada PT.

Perindustrian dan Perdagangan

Crumb Rubber Pekanbaru). JOM

FEKON, 2(1), 1-10. Retrieved from

https://www.jom.unri.ac.id

Mangkunegara, A. P. (2008). Sumber daya

manusia perusahaan. Bandung:

Remaja Rosdakarya.

Mukuan, A. S. (2014). Pengaruh kualitas kehidupan kerja terhadap kinerja karyawan pada PT. Bank Sulut kantor pusat. Jurnal Administrasi Bisnis, 1(2), 9-18. Retrieved from https:// ejournal.unsrat.ac.id

Nurandini, A., \& Lataruva, E. (2014). Analisis pengaruh komitmen organisasi terhadap kinerja karyawan ( studi pada pegawai perum PERUMNAS Jakarta ). Jurnal Studi Manajemen Dan Organisasi, 11,
78-91. Retrieved from http://www. ejournal.undip.ac.id

Parinding, R. G. (2015). Analisis pengaruh komitmen afektif, komitmen berkelanjutan, dan komitmen normatif terhadap kinerja karyawan pada PT.Pegadaian (persero) cabang Ketapang. E-Jurnal Ilmu Manajemen MAGISTRA, 1(2). Retrieved from http://www.tesis.narotama.ac.id

Riady, H. (2009). Winning the organizational commitment with quality of work life. Jurnal Institut Bisnis Dan Informatika Indonesia, $8(2), 56-63$.

Robbin, S. P. (1996). Organizational behavior, concept, controversus and aplication. New York: Prentice Hall.

Robbin, S. P., \& T.A., Judge. (2008). Perilaku organisasi (12th ed.). Jakrta: Salemba Empat.

Rosita, T., \& Yuniati, T. (2016). Pengaruh kepuasan kerja terhadap kinerja karyawan dengan komitmen organisasional sebagai variabel intervening. Jurnal Ilmu Dan Riset Manajemen, 5(1), 1-20. Retrieved from http://www.respository.stiesia. ac.id

Sapitri, R. (2016). Pengaruh komitmen organisasi terhadap kinerja karyawan 
Perusahaan Listrik Negara area

Pekanbaru. JOM Fisip, 3(2), 1-13.

Retrieved from https://jom.unri.ac.id

Sudaryatun, W. (2014). Pengaruh kualitas kehidupan kerja dan konflik peran terhadap komitmen organisasi dengan kepuasan kerja sebagai variabel intervening di BPS Propinsi D.I. Yogyakarta. JBTI, V(1), 94-125. Retrieved from http://journal.umy. ac.id

Sudibyo, Hartono, S., \& Maas, A. (2014). Analisis kinerja karyawan divisi mill dan boiler PT Gula Putih Mataram. Agro Ekonomi, 25(2), 205-215.
Retrieved from https://jurnal.ugm. ac.id/jae

Urbayatun, S., \& Widhiarso, W. (2012). Variabel mediator dan moderator dalam penelitian psikologi kesehatan masyarakat. Psikologi, 39(2), 180188. Retrieved from https://jurnal. ugm.ac.id

Windari, A. (2014). Pengaruh kepuasan kerja dan disiplin kerja terhadap kinerja karyawan PT. Pos Indonesia (Persero) Malang. Journal Riset Mahasiswa Manajemen (JRMM), 2(1), 1-15. Retrieved from http:// ejournal.unikama.ac.id 